\title{
Morphological evolution of Cuban super heavyweight boxers, 1976-2014
}

\author{
Wiliam Carvajal Veitía', Sofía Alberta León Pérez', María Elena González Revuelta', Yanel Deturnel Campo² \\ 'Suddirección de Docencia e Investigaciones. Instituto de Medicina del Deporte. La Habana. Cuba. Red Iberoamericana de Investigadores en Antropometría Aplicada. ${ }^{2}$ Subdirección \\ de Docencia e Investigaciones. Instituto de Medicina del Deporte. La Habana.Cuba. ${ }^{3}$ Departamento de Cineantropometría. Instituto de Medicina del Deporte. La Habana.Cuba
}

doi: 10.18176/archmeddeporte.00056

Received: 01/09/2020 Accepted: 12/05/2021

Key words: Anthropometry. Body Composition. Somatotype. Boxing.

\section{Summary}

Objective: To evaluate the morphological changes of Cuban super heavyweight boxers, more and less successful, through the period 1976-2014.

Material and method: Thirty super heavy boxers, who were members of the Cuban national teams in the period 1976-2014, were compared; The strategy consisted of separating the group in the periods 1976-1989, 1990-1999, 2000-2009 and 20102014. Sixteen anthropometric dimensions were recorded (weight, height, sitting height, six skinfold thickness, five girths and two breadths), from which the body composition and the somatotype were obtained. The data were analyzed applying the Analysis of variance (ANOVA). The conglomerate analysis based on the Euclidean distance was used in order to evaluate the correspondence between physical development and sports performance. A discriminant analysis was carried out in order to analyze the contribution of the anthropometrical variables to the variance of different clusters.

Results: Most of the anthropometric dimensions and indicators showed significant differences, having an impact on the increase in adiposity, body fat and endomorphy $(p<0.05)$, as well as the decrease in the indicators dependent on height $(p<0.05)$. The analysis by conglomerates, as well as the study of the Migratory Distances of the somatotype, showed that the Olympic medalist boxers differed in terms of the characteristics of body composition and in terms of the intensity of the somatotype changes in the period 1976-2014.

Conclusions: The Cuban boxer of the super heavyweight category showed a wide range of morphological demands, but these were framed within the international trends of professional boxers. The morphological attributes of the Olympic medalists differed from each other, and from the rest of the boxers investigated over time. These results provide anthropometric data of high scientific value, both for selection and for medical control of training.

\section{Evolución morfológica de boxeadores superpesados cubanos, 1976-2014}

\section{Resumen}

Objetivo: Evaluar los cambios morfológicos de boxeadores superpesados cubanos, más y menos exitosos, a través del período 1976-2014

Material y método: Treinta boxeadores superpesados, los cuales fueron miembros de las selecciones nacionales de Cuba en el periodo 1976-2014 fueron comparados; la estrategia consistió en separar el grupo en los periodos 1976-1989,1990-1999, 2000-2009 y 2010-2014. Se registraron 16 dimensiones antropométricas (peso, estatura, estatura sentada, seis panículos adiposos, cinco perímetros y dos diámetros óseos), a partir de las cuales fue obtenida la composición corporal y el somatotipo. Las comparaciones fueron realizadas aplicando un Análisis de varianza (ANOVA). Fue empleado el análisis de conglomerado basado en la distancia euclidiana con el objetivo de evaluar la correspondencia entre el desarrollo físico y el resultado deportivo. Un análisis discriminante fue realizado con el objetivo de analizar la contribución de las variables antropométricas a la varianza de los diferentes clústeres.

Resultados: La mayoría de las dimensiones antropométricas e indicadores mostraron diferencias significativas, repercutiendo en el aumento de la adiposidad, grasa corporal y la endomorfia $(p<0,05)$, así como la disminución de los indicadores dependientes de la estatura $(p<0,05)$. El análisis por conglomerados, así el estudio de las Distancias Migratorias del somatotipo arrojaron que los boxeadores medallistas olímpicos se diferenciaron en cuanto a las características de la composición corporal y en cuanto a la intensidad de los cambios del somatotipo en el periodo 1976-2014.

Conclusiones: El boxeador cubano de la categoría superpesado mostró un amplio rango de demandas morfológicas, pero

Palabras clave:

Antropometría.

Composición Corporal. Somatotipo. Boxeo. estas se enmarcaron dentro de las tendencias internacionales de boxeadores profesionales. Los atributos morfológicos de los medallistas olímpicos se diferenciaron entre sí,y del resto de los boxeadores investigados a través del tiempo. Estos resultados proporcionan datos antropométricos de elevado valor científico, tanto para la selección, como para el control médico del entrenamiento. 


\section{Introduction}

In the research carried out in Cuba on boxers, based on databases of more than 1,500 boxers participating in international competitions, their anthropometric profile is situated between the scope of 7.7 and 15.2\% body fat, obesity lower than the 4th percentile channel for the most successful boxers, between $84.8 \%$ and $92.3 \%$ of fat-free mass, a predominantly balanced meso-mectomorphic or mesomorphic somatotype, as well as a relative predominance of limbs over trunk $k^{1-3}$.

Related to boxing, research on the anthropometric characteristics in super heavyweights is scarce, since most studies usually make groupings out of convenience that include such subjects within very heterogeneous groups of competitive categories that are usually those greater than $81 \mathrm{~kg}^{1,4-8}$.

The morphological profile of Cuban super heavyweight boxers could constitute a characteristic model of the successful boxer in this competitive category. This proposition is reinforced by the international record achieved in the period 1972-2014, during which the country garnered 10 youth world titles, 11 Pan American Games titles, 9 world seniors championships, as well as 5 Olympic golds of the 12 awarded in the Olympics since $1972^{9}$.

Norton et al. evaluated data from other authors and concluded that, on average, the modern super heavyweight champion is taller and heavier than predecessors from the beginning of the century. However, related to larger boxers, they suggested that the advantages of greater absolute muscle power in striking are not as great as the disadvantages regarding speed and agility ${ }^{10}$.

Achieving morphological optimization is a higher level of sports development that has been defined as: "the achievement of an optimal physical structure, somatotype and body composition that allows greater efficiency in sports performance ${ }^{\prime \prime 10}$. This phenomenon takes place within and through the generations. Indeed, athletes'morphologies are susceptible to improve when they move up to a higher competitive level and simply in accordance with sports development throughout the decades. The result of which is a new conceptual model, via adaptive evolution, for the biomedical monitoring of athlete training ${ }^{11}$.

The phenomenon of morphological evolution in super heavyweight boxers has been scarcely documented in the specialized literature. Thus, the objective of this work is to evaluate the morphological evolution of Cuban super heavyweight boxers - the successful and lesser so_-during the period 1976-2014.

\section{Material and method}

This is a descriptive, longitudinal and retrospective study. Boxers were evaluated in the pre-competitive stage of preparation.

\section{Sample}

A total of 30 boxers of the super heavyweight category between 20 and 29 years old (24.2 \pm 3.2$)$, members of Cuba's national boxing teams. Their sporting age was between 9 and 17 years (13.2 \pm 4.0 ). Only those with at least one international participation between the
Olympic cycles between 1976 and 2014 were selected. The periods compared were: 1976-1989 (n=6), 1990-1999 (n=7), 2000-2009 (n=7) and 2010-2014 ( $n=10)$.

The sample consisted of $16.6 \%$ Olympic medalists, $16.7 \%$ world champions, 33.3\% Pan American champions, 16.7\% youth world champions. Of those evaluated, 56.6\% ( $n=17)$ were average boxers (Pr.), with no relevant record at the Pan American, world or Olympic level.

\section{Experimental design}

The ethics committee of Cuba's Sports Medicine Institute approved the use of the data for this study as the research was carried out with respect for the principles established by the Declaration of Helsinki ${ }^{12}$.

The technical staff of the Department of Cineanthropometry of Cuba's Sports Medicine Institute, where the national reference laboratory for Advancement in Cineanthropometry is located, performed the evaluations.

The selected anthropometric dimensions were evaluated according to the methodology used in the 1976 Montreal Olympic Games Anthropological Project (MOGAP) ${ }^{13}$.

The dimensions evaluated were: (1) body weight (kg), height (cm), sitting height (cm); (2) six adipous panicles (mm): triceps, subscapular supraspinal, abdominal, thigh and leg; (3) five circumferences (cm): normal chest, waist, flexed arm, mid-thigh and medial calf; (4) two bone diameters (cm): humerus and femur. The equipment used included the balance (Detecto, USA) of $0.1 \mathrm{~kg}$ precision for the measurement of body weight; a stadiometer (Holtain, UK) of $0.1 \mathrm{~mm}$ precision for height and sitting height; four panicle meters $\left(10 \mathrm{~g} / \mathrm{m}^{3}\right.$ ) of $0.2 \mathrm{~mm}$ precision (Holtain, UK); two precision thickness gauges of $1 \mathrm{~mm}$ precision to determine bone diameters and three tape measures of $1 \mathrm{~mm}$ precision (Holtain, UK) to measure circumferences.

From the anthropometric dimensions obtained, the body mass index (BMI) of each pugilist was determined using the formula: weight $(\mathrm{kg}) /$ height $(\mathrm{m})^{2}$. Body composition (BC) was analyzed via the sum of the six panicles $(\mathrm{mm})$ used, as well as a regression equation obtained from the data of Withers et al. from 1987. From this, body density was obtained, from which the percentage of fat, kilograms of fat and kg of active body mass were derived. The Active Body Substance Index was calculated using the formula: active body mass/height $\left(\mathrm{cm} / \mathrm{g}^{3}\right)^{14}$. The formula used to obtain the percentage of fat from body density (BD) was as follows ${ }^{13}$

$$
\begin{gathered}
\mathrm{BD}=1.1026-0.00031^{*}(\mathrm{Age})-0.000036^{*}(\mathrm{~S} 6 \mathrm{p}) \\
\mathrm{R}^{2}=0.738 ; \mathrm{EEE}=0.00579 \mathrm{~g} / \mathrm{cm}^{3} \text { and } 2.5 \% ; \\
\quad \text { Application range: } 15-39 \text { years }
\end{gathered}
$$

S6p being the sum of the subscapular, triceps, supraspinal, abdominal, mid-thigh and calf skinfolds. R2: formula coefficient of determination. EEE: Standard Error of the Estimate.

The analysis of the Heath-Carter anthropometric somatotype included determining its components, plotting them in the somatochart, as well as determining the Somatotype Altitudinal Distance (SAD) and the Migratory Distances (DM), which allowed the dispersion of the individual somatotype to be determined with respect to the group and the intensity of related changes through the decades ${ }^{15}$. 


\section{Statistical analysis}

A descriptive analysis of the data was performed to calculate central tendencies and dispersion (mean \pm standard deviation). The relative amounts of the somatotype categories were also obtained.

The Somatotype Altitudinal Distance was converted into the Somatotypical Altitudinal Mean (MAS) by estimating its average. Individual estimates of the Somatotype Altitudinal Distance for Olympic medalists of each period were compared to the Somatotypical Altitudinal Mean of their period.

For each variable, an analysis of variance (ANOVA) was performed to verify the assumption of equality of means between the competitive periods 1976-1989, 1990-1999, 2000-2009 and 2010-2014. For each variable analyzed, the assumptions of randomness, normality and homogeneity of variance were verified through the tests of runs, Shapiro-Wilk and Levene, respectively. Welch's robust mean comparison test was used to analyze five variables where the assumption of normality was not met (sitting height, supraspinal skinfold, mid-thigh skinfold, obesity, fat percentage). Multiple Bonferroni and Games-Howell comparisons were used to determine the magnitude of significant differences between competitive periods.

In order to assess the correspondence between physical development and sports outcome, cluster analysis was used employing the Ward agglomeration method and Euclidean distances as a measure. The analysis included the 16 studied dimensions, body composition indicators and somatotype. For this procedure, the athletes were categorized according to their track record: average boxer (Pr.), Pan American champion (CP), Olympic medalist (MO), Olympic champion (CO), junior world champion (CMJ) and junior world medalist (MMJ).
A discriminant analysis, with Ward scores as an independent variable, was used as an exploratory technique to define which variables contributed most to the variability between the clusters obtained. Stepwise regression was used for this analysis.

The statistical processing of the data was carried out with the IBM SPSS statistical package, version 21.0 (Inc, Chicago, Illinois, United States) for Windows. The level of significance set for all contrasts was $p<0.05$.

\section{Results}

Table 1 shows the descriptive statistics (mean \pm standard deviation) for the evaluated anthropometric dimensions, the results of the analysis of variance, and the post hoc multiple comparison test.

Of the 16 anthropometric dimensions, only six showed significant differences when contrasting the studied periods. The boxers studied were significantly different in height, supraspinal, abdominal and midthigh skinfolds, waist and mid-thigh circumferences $(p<0.05)$.

The multiple post hoc comparison revealed that the boxers of the period 1976-1989 (A) were significantly taller than those of the periods 2000-2009 (C) and 2010-2014 (D); they also had a smaller supraspinal, abdominal, and mid-thigh skinfold, in addition to waist circumference than those of the other competitive periods $(p<0.05)$. Regarding the circumference of the thigh, it was only significantly different from the other groups (A, B, D) in the period 2000-2009 (C).

Table 2 shows the characteristics of the $B C$ and the somatotype in each of the evaluated stages, as well as the results of the analysis of variance and the post hoc test.

Table 1. Mean and standard deviation (mean \pm standard deviation) of the anthropometric dimensions of super heavyweight boxers by generations.

\begin{tabular}{|c|c|c|c|c|c|c|}
\hline & $\begin{array}{c}1976-1989 \\
(N=6)\end{array}$ & $\begin{array}{c}1990-1999 \\
(\mathrm{~N}=7)\end{array}$ & $\begin{array}{c}2000-2009 \\
N=7\end{array}$ & $\begin{array}{c}2010-2014 \\
N=10\end{array}$ & Sig. & Post hoc Test \\
\hline Weight & $100.7 \pm 5.2$ & $103.0 \pm 7.1$ & $104.4 \pm 8.6$ & $104.9 \pm 8.5$ & $0.160^{\text {ns }}$ & \\
\hline Height & $193.2 \pm 3.9$ & $192.5 \pm 5.5$ & $189.5 \pm 7.7$ & $189.2 \pm 5.1$ & $0.03^{*}$ & $A, B$ vs $C, D$ \\
\hline Sitting height & $95.8 \pm 2.6$ & $94.7 \pm 2.6$ & $95.5 \pm 3.3$ & $94.5 \pm 1.4$ & $0.433^{\text {ns }}$ & \\
\hline \multicolumn{7}{|l|}{ Adipous panicles } \\
\hline Subscapular & $13.0 \pm 2.2$ & $16.4 \pm 6.4$ & $14.6 \pm 4.9$ & $17.4 \pm 6.6$ & $0.07^{\mathrm{ns}}$ & \\
\hline Triceps & $9.8 \pm 2.7$ & $11.6 \pm 6.3$ & $13.0 \pm 4.5$ & $14.4 \pm 5.5$ & $0.144^{\mathrm{ns}}$ & \\
\hline Supraspinal & $9.8 \pm 2.6$ & $11.0 \pm 5.7$ & $11.6 \pm 4.6$ & $12.6 \pm 6.0$ & $0.04^{*}$ & $A$ vs $B, C, D$ \\
\hline Abdominal & $13.4 \pm 4.3$ & $18.2 \pm 9.9$ & $16.6 \pm 3.4$ & $25.0 \pm 11.7$ & $0.02^{*}$ & A vs B.D \\
\hline Mid-thigh & $9.4 \pm 2.0$ & $14.0 \pm 6.0$ & $15.8 \pm 3.7$ & $16.0 \pm 9.3$ & $0.004^{*}$ & A vs $C$ \\
\hline Medial calf & $7.8 \pm 3.2$ & $10.1 \pm 4.0$ & $12.1 \pm 4.1$ & $11.2 \pm 2.0$ & $0.07^{\mathrm{ns}}$ & \\
\hline \multicolumn{7}{|l|}{ Perimeters } \\
\hline Normal thorax & $106.8 \pm 2.3$ & $108.0 \pm 2.9$ & $111.7 \pm 1.9$ & $107.2 \pm 1.8$ & $0.302^{\mathrm{ns}}$ & \\
\hline Flexed arm & $37.6 \pm 1.11$ & $38.2 \pm 1.50$ & $39.0 \pm 2.6$ & $37.9 \pm 1.2$ & $0.421^{\mathrm{ns}}$ & \\
\hline Waist & $86.5 \pm 0.8$ & $88.8 \pm 4.5$ & $90.1 \pm 0.2$ & $89.7 \pm 2.7$ & $0.007^{*}$ & $A$ vs $C, D$ \\
\hline Mid-thigh & $58.9 \pm 1.7$ & $60.9 \pm 2.9$ & $63.9 \pm 4.2$ & $56.6 \pm 5.6$ & $0.04^{*}$ & $C$ vs $\mathrm{A}, \mathrm{B}, \mathrm{D}$ \\
\hline Middle leg & $40.6 \pm 2.8$ & $41.0 \pm 3.4$ & $41.9 \pm 5.1$ & $41.4 \pm 4.3$ & $0.715^{\text {ns }}$ & \\
\hline \multicolumn{7}{|l|}{ Diameters } \\
\hline Humerus & $7.5 \pm 0.90$ & $7.7 \pm 0.64$ & $7.6 \pm 0.63$ & $7.6 \pm 0.61$ & $0.976^{\text {ns }}$ & \\
\hline Femur & $10.3 \pm 0.22$ & $10.4 \pm 0.44$ & $10.5 \pm 0.50$ & $10.6 \pm 0.48$ & $0.758^{\text {ns }}$ & \\
\hline
\end{tabular}

${ }^{*} p<0,05 ;$ ns: $p>0,05 ; A: 1976-1989 ; B: 1990-1999 ; C: 2010-2009 ; D: 2010-2014$ 
With the exception of body mass index, active body mass and mesomorphy, all indicators showed significant differences between competitive periods after the analysis of variance $(p<0.05)$. In turn, the multiple post hoc comparison tests revealed that the super heavyweight boxers of the period 1976-1989 (A) had a significantly lower sum of skinfolds, percentage, kilograms of fat, active body substance index and endomorphy than those of other competitive periods $(p<0.05)$. The boxers of the period 1976-1989 revealed a significantly higher ectomorphy than those of other competitive periods $(p<0.05)$.

The average somatotype in each of the studied periods was mesoendomorphic; the average super heavyweight became increasingly endomorphic and mesomorphic, while ectomorphy became less represented. From the qualitative point of view, $66.7 \%$ of the boxers were mesoendomorphic, 20\% balanced mesomorphic, in addition to some mesomorphic-endomorphic (6.6\%), mesoectomorphic (3.3\%) and endomesomorphic (3.3\%) types.

By comparing the Somatotypical Altitudinal Mean to the Somatotype Altitudinal Distance of the Olympic medalists in each period, it was found that while the somatotype was relatively homogeneous in all periods (MAS $<2$ ), the somatotype of the medalists differed more and more from the average of the boxers within their period (SAD>SAM). This difference became more marked as time advanced, given that the medalists' estimates were 1.82; 2.24; 2.71 and 2.93 for the periods 1976 1989, 1990-1999, 2000-2009 and 2010-2014, respectively.

The dendrogram in Figure 1 was obtained through a cluster analysis. Each subject was considered individually in this analysis. All subjects' differences were analyzed with respect to the subjects assigned to the different clusters. Three clusters were derived from this analysis, defined as follows: CP3 to Pr3 (cluster 1), Pr4 to CP2 (cluster 2), and CP4 to $\mathrm{CO} 3$ (cluster 3).

To determine the optimal number of clusters, the agglomerations schedule produced by the analysis was observed to show at what stage the first sudden acceleration in cluster formation occurred. The union of case 1 with case 2 was chosen where the inflection was found with a coefficient of 436,662 .

A distinguishing note regarding the different clusters is that all boxers from the period 1976-1989 appeared in cluster 2; those from 2010 to 2014 were distributed in the two extreme clusters (cluster 1 and 3$)$. Another trend found is that $61.5 \%(n=8)$ of the medalists were in cluster 2; cluster 1 included only 15.3\% ( $n=2)$ and cluster 3 included the remaining $23.5 \%(n=4)$. Cluster 1 included the most average boxers (Pr.), accounting for $41.2 \%(n=7)$; cluster 2 included $35.3 \%(n=6)$, and cluster 3 was made up of $23.5 \%$ average boxers $(n=4)$.

The discriminant analysis yielded a single significant canonical function that explained $100 \%$ of the variance in the clusters based on the sum of the six adipose panicles $(\lambda=0.088 ; \mathrm{gl}=2 ; \mathrm{p}=0.000$; canonical correlation=0.955). Wilks'lambda test for differences in equality between

Figure 1. Dendrogram of super heavyweight boxers.

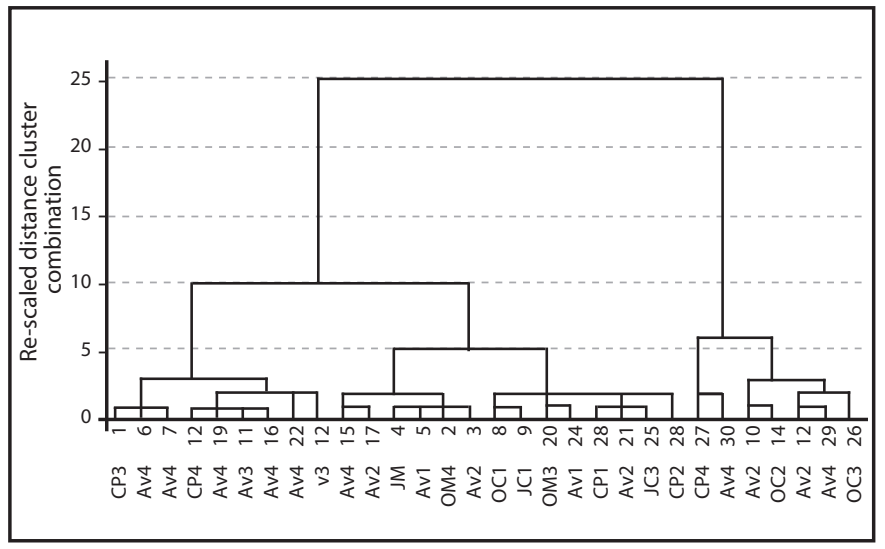

Av: average boxer; PAC: Pan American champion; OM: Olympic medalist; OC: Olympic champion; JC: Junior world champion; JM: Junior world medalist; 1: 1976-1989; 2: 19901999; 3: 2000-2009; 4: 2010-2014.

Table 2. Body composition, somatotype and altitudinal distance from the somatotype.

\begin{tabular}{|c|c|c|c|c|c|c|}
\hline & $\begin{array}{c}1976-1989 \\
(N=6)\end{array}$ & $\begin{array}{c}1990-1999 \\
(N=7)\end{array}$ & $\begin{array}{c}2000-2009 \\
N=7\end{array}$ & $\begin{array}{c}2010-2014 \\
N=10\end{array}$ & Sig. & Post Hoc Test \\
\hline \multicolumn{7}{|l|}{ Body composition } \\
\hline Body mass index & $27.0 \pm 2.1$ & $27.8 \pm 1.4$ & $29.1 \pm 2.9$ & $29.3 \pm 3.1$ & $0.195^{\mathrm{ns}}$ & \\
\hline Sum of 6 fatty skinfolds & $63.4 \pm 11.6$ & $73.8 \pm 30.5$ & $80.7 \pm 22.9$ & $95.2 \pm 34.4$ & $0.03^{*}$ & $A$ vs $C, D$ \\
\hline Fat percentage (Withers et al.) & $11.7 \pm 1.7$ & $12.8 \pm 4.8$ & $14.1 \pm 3.6$ & $16.7 \pm 5.7$ & $0.04^{*}$ & $A$ vs $C, D$ \\
\hline $\mathrm{Kg}$ of fat & $11.8 \pm 2.0$ & $13.2 \pm 5.2$ & $14.8 \pm 4.7$ & $16.1 \pm 7.6$ & $0.04^{*}$ & $A$ vs $C, D$ \\
\hline $\mathrm{Kg}$ Active body mass & $88.9 \pm 3.8$ & $89.8 \pm 6.8$ & $89.5 \pm 6.8$ & $88.5 \pm 4.0$ & $0.965^{\mathrm{ns}}$ & \\
\hline Active body substance index & $1.23 \pm 0.11$ & $1.26 \pm 0.05$ & $1.32 \pm 0.11$ & $1.31 \pm 0.10$ & $0.04^{*}$ & $A$ vs $C, D$ \\
\hline \multicolumn{7}{|l|}{ Somatotipo } \\
\hline Endomorphy & $2.9 \pm 0.68$ & $3.1 \pm 1.37$ & $3.4 \pm 1.30$ & $4.2 \pm 1.30$ & $0.007^{*}$ & $A$ vs $D$ \\
\hline Mesomorphy & $5.2 \pm 1.37$ & $5.5 \pm 0.65$ & $5.7 \pm 0.98$ & $6.2 \pm 1.21$ & $0.349^{\text {ns }}$ & \\
\hline Ectomorphy & $1.8 \pm 0.90$ & $1.5 \pm 0.61$ & $1.2 \pm 0.77$ & $1.2 \pm 0.91$ & $0.01^{*}$ & $A$ vs $B, C, D$ \\
\hline \multicolumn{7}{|l|}{ Homogeneity indices } \\
\hline Mean altitudinal somatotype & $1.81 \pm 0.63$ & $1.5 \pm 0.57$ & $1.47 \pm 0.70$ & $1.87 \pm 0.95$ & $0.04^{*}$ & $A$ vs $B, C$ \\
\hline
\end{tabular}

${ }^{*} p<0,05 ;{ }^{n s}: p>0,05 ; A " 1976-1989 ; B: 1990-1999 ; C: 2010-2009 ; D: 2010-2014$ 
group means showed that the clusters differed significantly in terms of the sum of the six adipose panicles $(p<0.05)$. The stepwise inclusion method discarded the rest of the variables included in the research as independent variables.

Figure 2a shows the general distribution of the studied group. The average trend throughout the studied periods is shown in Figure 2b; it was found that the average somatotype became increasingly endomorphic and mesomorphic over time. Figure $2 c$ only reflects the Olympic medalists of each period; the same evolution as in Figure $2 b$ was not found. This last aspect was quantified based on the estimate of the DM, which evidenced a low-intensity evolution for the average somatotype between the periods ( $\mathrm{MD}=1.88$ units) with respect to $2 \mathrm{c}$; the intensity of change in somatotype for medalists was 4.05 times higher than the group average (MD=7.62 units).

\section{Discussion}

Based on the research carried out in the main international databases (PubMed, Scopus, Scielo), only one anthropometric study was found related exclusively to boxers of the super heavyweight category, but it addressed aspects related to the morphological evolution of professional boxers $^{16}$. Therefore, the present work could be the first to address the characteristics of physical development and its evolution in amateur elite boxers of the super-heavyweight category. The result contributes knowledge regarding elite boxers' anthropometric characteristics, es- pecially since the analyzed sample was made up of athletes with broad competitive achievements at an international level.

By analyzing a series of data provided by Norton and Olds on the evolution of athletes in the twentieth century ${ }^{17}$, as well as the research carried out by Han et al. ${ }^{16}$ on the evolution of super heavyweight boxers in the period 1889-2019, the authors of this study consider that the weights and heights of the average Cuban super heavyweight did not differ from those found in the examined professional boxers. One of the causes for this may be that, while at the international level, height and weight increases were obtained over the years, according to the aforementioned authors, the average Cuban pugilist had already achieved optimized values for these variables in the 1970s.

This research demonstrates that the competitive success of the boxers studied was related to a wide range of morphological demands. But when reviewing other research, it was found that these characteristics were within the morphological variability of professional boxers internationally. For instance, in Han et al. ${ }^{16}$, lower results were obtained for body weight $(97.5 \pm 11.5 \mathrm{~kg})$ and height $(187.3 \pm 6.5 \mathrm{~cm})$, but were similar in BMI $\left(27.8 \pm 2.4 \mathrm{~kg} / \mathrm{m}^{2}\right)$ for international professional boxers. On the other hand, the results achieved were similar to those obtained by Norton and Olds ${ }^{16}$. By modeling professional boxers' morphological evolution in the period 1970-2000, these authors showed that incremental rates for body weight ( $1 \mathrm{~kg} /$ decade) and height $(0.6 \mathrm{~cm} /$ decade) led super heavyweight boxers to achieve results similar to those of the present research.

Figure 2. Somatotype distribution of super heavyweight boxers.

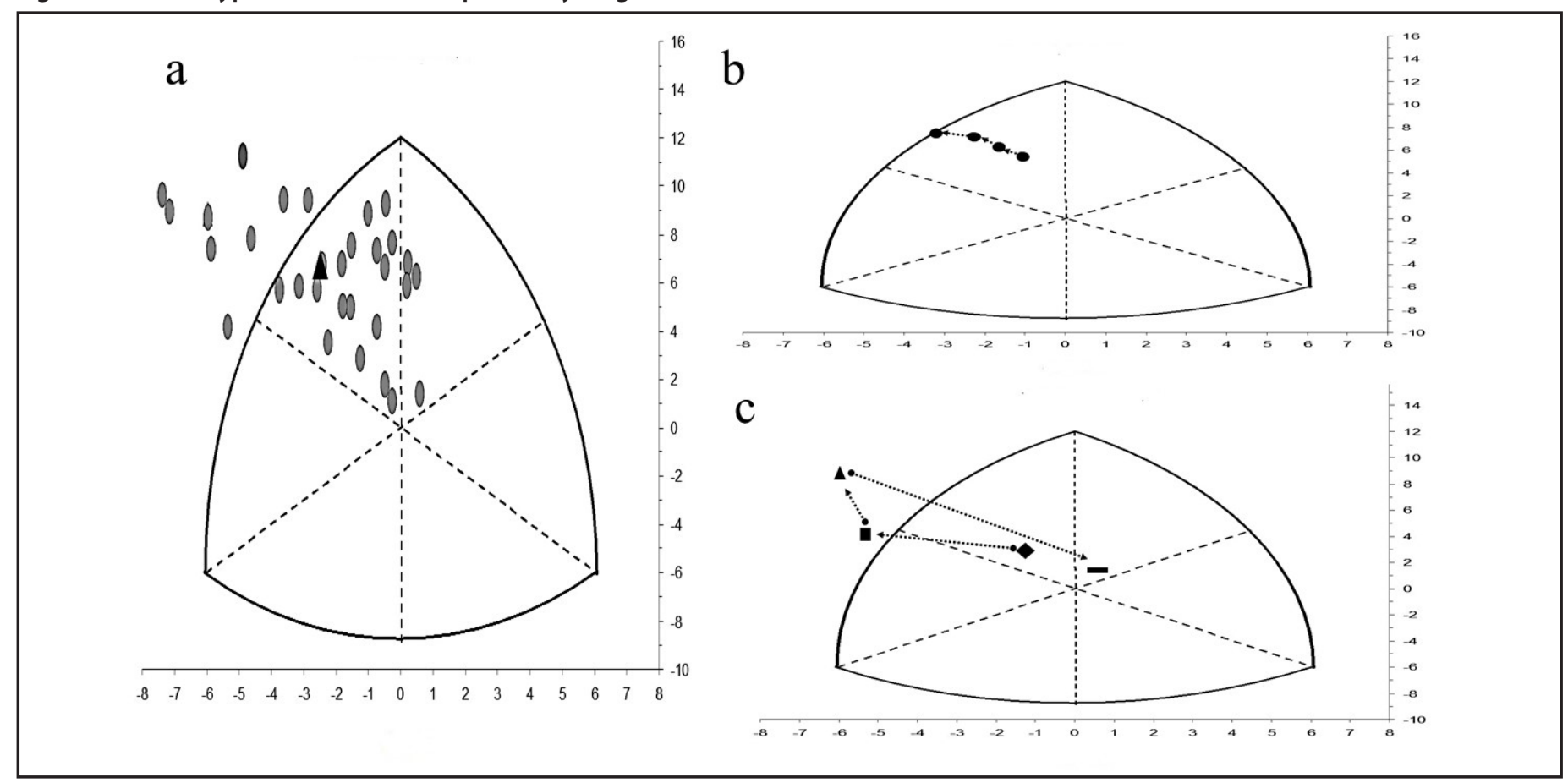

a: individual somatopoints and centroids $(\mathbf{\Lambda})$; b: average somatotype $(\bullet)$ by periods, where $\leftarrow=$ direction following the average somatotype from $1976-1989$ to 2010-2014. migration of the individual somatotype, where: $\bullet=$ Olympic medalist from the period 1976-1989; $\mathbf{\square}=$ Olympic medalist from the period $1990-$ 1999; $\boldsymbol{\Delta}$ = Olympic medalist from the period 2000-2009; - = Olympic medalist from the period 2010-2014 
Han et al. ${ }^{16}$ obtained significant correlations by relating variables that define obesity ( $r$ between 0.248-0.603), muscularity ( $r$ between 0.239$0.510)$ and bone development ( $r=0.312$ ) with the year of measurement. These authors attributed the changes found in the body mass index of professional champions to the century-related evolution in their musculoskeletal development. In the examined boxers they found that an increase in body mass index over the century could be due to increased obesity, being accompanied by increases in waist circumference.

In the present research, a significant average increase in the sum of skinfolds, percentage of fat and kilograms of fat was found, with a relatively constant body mass index and active body mass. This finding demonstrates the difference in body composition between boxers who competed in the period 1976-1989 and those who competed after this period.

From the methodological point of view, this research constitutes an advance that allows us to elucidate the true advances in body composition and somatotype during the evolution process, which have been discerned essentially on the basis of the body mass index in other investigations ${ }^{10,16,18,19}$. Only a limited number of studies -in other sports-have shown how the somatotype and some component of body composition vary through the decades ${ }^{20-23}$.

In a research study carried out in the Spanish sports population, it was found that a BMI of up to $32.8 \mathrm{~kg} / \mathrm{m}^{2}$ in athletes can be considered overweight due to the development of the lean component and not of obesity ${ }^{24}$. However, when research is aimed at evaluating morphological evolution over the decades, the use of BC and somatotype become relevant owing to the uncertainty of BMI to quantify lean and fatty components in the sports population.

It was shown that the somatotype of the average Cuban super heavyweight boxer was mesoendomorphic during the period under analysis. However, the endomomorphic component gradually increased while the ectomorphic component decreased. The fact that the average somatotype has evolved so much reflects the range of variability in which these athletes could be successful, an aspect that was demonstrated in previous research carried out in samples of Cuban and foreign boxers ${ }^{2,3,25}$.

The cluster analysis confirmed that the athletes' sports-related outcomes were not necessarily associated with physical development, as has occurred in other sports ${ }^{26-28}$. Even so, there was a higher proportion of medalists in cluster 2 with all the boxers of the decade between 1976-1989. These boxers were precisely those with lower values in percentage of fat, kilograms of fat and endomorphy. In addition, they had greater stature and linearity, a determining factor for competitive success in boxing, as demonstrated in previous research ${ }^{29}$.

A greater number of athletes may be encountered in cluster 2 owing to the fact that, in their search for morphological optimization, headhunters particularly searched for super heavyweight boxers with the physical attributes of the boxers that had developed in the 1970s and 1980s. This is substantiated by the fact that, in this historical period, Cuban researchers managed to characterize the profile of a standard male athlete in this division in the international and national levels ${ }^{2}$. In addition, in this period, Cuban super heavyweight boxers marked their relevance by having the only three-time Olympic champion in this division ${ }^{3}$.

The results of the discriminant analysis revealed that the sum of the adipose panicles was the only variable that contributed decisively to the variance associated with the morphological differences between the athletes under investigation. The notable contribution of this variable also demonstrates that it was the determining factor that contributed most to changes in body composition through the studied generations.

Although this statistical analysis is not very frequently used in this type of research, other authors have recommended it to understand how athletes adjust their anthropometric characteristics according to their sports discipline or their performance ${ }^{26-30}$. In the present research, doing so was very useful as it made it possible to describe the group in terms of its morphometric similarities, in addition to observing behavior patterns in the periods under examination.

\section{Conclusions}

Cuban boxers of the super heavyweight category proved to have a wide range of morphological demands, which were in keeping with international trends among professional boxers despite their changes over time. Olympic medalists' morphological attributes differed from one another over time and in relation to the other examined boxers. These results provide anthropometric data of high scientific value, both in the interest of this selection and for medical monitoring of training.

\section{Conflict of interest}

The authors declare that there is no conflict of interest.

\section{Bibliography}

1. Rodríguez CA, Sánchez G, García E, Martínez M, Cabrera T. Contribution to the study of the morphological profile of highly competitive male Cuban athletes. Boletín Científico Técnico INDER. 1986;1:6-24.

2. Rodríguez CA. Aproximación hacia el cálculo del peso adecuado en la preparación del deportista. Boletín científico-técnico, INDER. 1989;2:5-32.

3. Rodríguez CA, Fernández MC, Martínez M, MartínezX. Adaptación del sistema O-Scale (adiposidad) para su aplicación en boxeadores. Consideraciones metodológicas. Rev Cub Med Dep \& Cul Fis. 1991;2:14-22.

4. Chaabene H, Tabben M, Mkaouer B, Franchini E, Negra Y, Hammami M et al. Amateur boxing: physical and physiological attributes. Sports Med. 2015;45:337-52.

5. Noh JW, Kim JH, Kim MY, Lee JU, Lee LK, Park BS, et al. Somatotype analysis of elite boxing athletes compared with nonathletes for sports physiotherapy. J Phys Ther Sci. 2014;26:1231-5.

6. Pons V, Riera J, Galilea PA, Drobnic F, Banquells M, Ruiz O. Características antropométricas, composición corporal y somatotipo por deportes. datos de referencia del CAR de San Cugat, 1989-2013. Apunts Med Esport. 2015;50:65-72.

7. Carter JEL. Physical Structure of Olympic athletes. Part 1: The Montreal olympic games anthropological project. Medicine and Sports, 16. Basel: Karger; 1982.

8. Canda AS. Variables antropométricas de la población deportista española. Ministerio de educación y cultura. Madrid: ICD; 2012.

9. Amateur boxing results; 2009. Disponible en: www.http://amateur-boxing.strefa.pl/ Championships/AAAChampionships.html. Consultado 01-09-2020. 
10. Norton Kl, Olds TS, Olive S, Craig NP. Anthropometry and sports performance. In K. Norton and T.S. Olds (Eds.) Anthropometrica. University of New South Wales Press: Sydney; 2000.

11. Carvajal W. Evolución morfológica en la población deportiva cubana en el período 1970-2010. implicaciones para su evaluación cineantropométrica. Universidad de las Ciencias de la Cultura Física y el Deporte. La Habana, 2018. Tesis Doctoral.

12. World Medical Association. Declaration of Helsinki: ethical principles for medical research involving human subjects. JAMA. 201;310:2191-4.

13. Withers RT, Craig NP, Bourdon PC, Norton KI. Relative body fat and anthropmetirc prediction of body density of male athletes. Europ J Appl Physiol. 1987;56:191-200.

14. Tittel K, Wutscherk H. Sportanthopometrie. Leipzig: Johann Ambrosius Bath; 1972.

15. Carter JEL, Heath BH. Somatotyping: development and applications, 1st edition. Cambridge, UK: Cambridge University Press; 1990.

16. Han TS, Callis TG, Sharma P, Lean MEJ. Secular trends in adiposity and musculoskeletal dimensions of elite heavyweight boxers between 1889 and 2019. Sport Sci Health. 2020;16:249-55.

17. Norton $\mathrm{K}, \mathrm{Old}, \mathrm{T}$. Morphological evolution of athletes over the 20th century: causes and consequences. Sport Med. 2001;31:763-83.

18. Sedeaud A, Marc A, Schipman J, Schaal K, Danial M, Guillaume M, Berthelot G, Toussaint JF. Secular trend: morphology and performance. J Sports Sci. 2014;32:1146-54.

19. Sands WA, Slater C, McNeal JR, Murray SR, Stone MH. Historical trends in the size of US olympic female artistic gymnasts. Int J Sports Phys Perform. 2012;7:350-6.

20. Lozovina V, Lozovina M, Pavičić L. Morphological changes in elite male water polo players. Acta Kinesiol. 2012;6:85-90.

21. Olds T. The evolution of physique in male rugby union players in the twentieth century.
J Sports Sci. 2001;19:253-62.

22. Carvajal W, Serviat N. Evolución del somatotipo de jugadores cubanos de voleibol en el periodo 1970-2012. Arch Med Deporte. 2014;31:384-90.

23. Carvajal W, León S, González ME, Echevarría I, Martinez M. Morphological changes of elite Cuban female volleyball players, 1984-2008. Rev Esp Antrop Fís. 2015;36:33-44.

24. Canda A. Deportistas de alta competición con índice de masa corporal igual o mayor a 30 kg/m². ¿Obesidad o gran desarrollo muscular? Apunts Med Esport. 2017;52:29-36.

25. Carvajal W, León S, Gonzalez ME, Deturnel Y, Echavarria I. Anthropometrical characteristics of cuban sporting population. Reference data from high performance national teams, 1992-2014. Apunts Med Esport. 2018;53:129-37.

26. Silva A, Sampaio A, Vilas-Boas JP, Fernandes RJ. Front crawl sprint performance: a cluster analysis of biomechanics, energetics, coordinative, and anthropometric determinants in young swimmers. Control Motor. 2016;20:209-21.

27. Van der Zwaard S, De Ruiter C, Jaspers RT, De Koning JJ.Antropometric Cluster of competitive cyclists and their sprint and endurance performance. Front. Physiol. 2019:10:1276

28. Bonilla DA, Peralta JO, Bonilla JA, Urrutia-Mosquera W, Vargas-Molina S, Cannataro R, et al. Morphology, body composition and maturity status of young colombian athletes from the Urabá subregion: A k-Medoids and hierarchical clustering analysis. J Hum Sport Exerc. 2020;15:1367-86.

29. Tshibangu AMN. Boxing performance of most boxers is directed by their ectomorphy ratings towards lowest percentages of victories and highest percentages of losses. APE. 2016;6:351-63.

30. Bautista IJ, Chirosa IJ, Robinson JE van der Tillaar R, Chirosa LJ, Martínez I. A New physical performance classification system for elite handball players: cluster analysis. $J$ Hum Kinet. 2016:56:131-42. 